\title{
PENGARUH LAYANAN INFORMASI DALAM BIMBINGAN PRIBADI TERHADAP KONSEP DIRI SISWA KELAS VIII SMP SWASTA MAJU TELAGA JERNIH KECAMATAN SECANGGANG TAHUN PELAJARAN 2016/2017
}

\author{
Suandari, Nurul Hasanah, Syaiful Sagala \\ STKIP Budidaya Binjai
}

\begin{abstract}
Abstrak
Pada perkembangan dan kehidupan setiap manusia sangat mungkin timbul berbagai permasalahan terhadap perkembangan konsep diri. Seperti adanya gejala perkembangan konsep diri negatif yang dialami oleh siswa sekolah menegah pertama. Perlu ditentukan adanya bimbingan sebagai suatu usaha pemberian bantuan yang diberikan baik kepada individu maupun kelompok dalam rangka memecahkan masalah yang dihadapinya. Pemberian layanan informasi perlu dilakukan karena dengan layanan informasi siswa diberikan pemahaman tentang kesan individu terhadap dirinya dan mengamati perilaku fisiknya secara langsung, serta memberikan pemahaman bagaimana merespon reaksi dari orang lain terhadap diri individu. Tujuan dalam penelitian ini adalah untuk membekali siswa atau individu dengan berbagai pengetahuan dan pengalaman tentang berbagai hal yang berguna untuk mengenal diri, merencanakan dan mengembangkan pola kehidupan mereka sebagai siswa, anggota keluarga dan masyarakat. Penelitian ini merupakan penelitian quasi eksperimen yang menggunakan teknik penelitian nonequivalen control group design dan uji hipotesis dilakukan dengan menggunakan teknik regresi. Hasil penelitian menunjukan bahwa Ha diterima, hal ini dibuktikan dengan perolehan nilai $\mathrm{F}_{\text {hitung }}>\mathrm{F}_{\text {tabel }}(2.73>$ 2.45) dengan kata lain terdapat pengaruh signifikan antara layanan informasi dalam bimbingan pribadi terhadap konsep diri siswa kelas VIII SMP Swasta Maju Telaga Jernih Kecamatan Secanggang Tahun Pelajaran 2016/2017.

kata kunci : layanan informasi dalam bimbingan pribadi, konsep diri
\end{abstract}

\section{PENDAHULUAN}

Hurlock berpendapat bahwa pada masa remaja konsep diri merupakan inti dari kepribadian dan sangat mempengaruhi proses perkembangan individu selanjutnya.[2] Oleh karena itulah agar perkembangan individu selanjutnya dapat berjalan dengan lancar, maka konsep diri individu remaja harus terbentuk secara baik. Semakin baik atau positif konsep diri seseorang maka akan semakin mudah ia mencapai keberhasilan. Sedangkan semakin jelek atau negatif konsep diri, maka akan semakin sulit seseorang untuk berhasil. Karena seseorang yang memiliki konsep diri negatif akan tumbuh dalam dirinya rasa tidak percaya diri, takut gagal sehingga tidak berani mencoba hal- hal yang baru dan menantang, merasa diri bodoh, rendah diri, merasa diri tidak berguna, pesimis, serta berbagai perasaan dan perilaku inferior lainnya.

Pada pengamatan yang dilakukan di SMP Swasta maju Telaga Jernih, peneliti menemukan banyak siswa yang memiliki konsep diri sangat rendah. Hal ini ditunjukan dengan sikap siswa yang sering berperilaku yang tidak sepantasnya dilakukan oleh siswa sebagai peserta didik, seperti menyakini dan memandang bahwa dirinya lemah, tidak berdaya, tidak dapat berbuat apa-apa, tidak kompeten serta kehilangan daya tarik terhadap hidup. Individu 
yang memiliki konsep diri negatif cenderung bersikap pesimis terhadap kehidupan dan kesempatan yang dihadapi. Hal ini terjadi karena para siswa belum bisa mengetahui dan mengenal dirinya atau konsep diri yang dimiliki dengan baik.

Untuk membantu mengenalkan diri siswa perlu adanya pembinaan dan layanan informasi yang berkaitan dengan bimbingan pribadi, sehingga mampu meningkatkan dan mengembangkan konsep diri yang dimiliki siswa. Layanan informasi merupakan suatu media yang memiliki ruang lingkup layanan untuk pemahaman dan pencegahan kepada peserta didik serta dapat menentukan arah suatu tujuan, sehingga menjadi jelas dan tidak salah dalam mengambil keputusan. Layanan informasi dapat digunakan sebagai acuan untuk bersikap dan berperilaku dalam rangka membentuk konsep diri siswa, sebagai pertimbangan bagi arah untuk pengembangan diri dan sebagai dasar pengambilan keputusan. Bimbingan merupakan bantuan yang diberikan kepada siswa dalam rangka upaya menemukan pribadi yang dimaksud agar siswa (peserta didik) mengenal kekuatan dan kelemahan dirinya sendiri, serta menerima secara positif dan dinamis sebagai modal pengembangan diri lebih lanjut serta membina konsep diri yang positif.

Sehubungan dengan adanya layanan informasi ini, para siswa diharapkan dapat memiliki kepercayaan diri mengenai hidupnya dimasa yang akan datang. Apabila tidak memperoleh informasi semacam ini selama belajar di sekolah, individu diperkirakan akan menghadapi masalah dan kesulitan di sekolah, lingkungan dan keluarga. Oleh karena itu layanan informasi bertujuan untuk membekali siswa atau individu dengan berbagai pengetahuan dan pengalaman tentang berbagai hal yang berguna untuk mengenal diri, merencanakan dan mengembangkan pola kehidupan mereka sebagai siswa, anggota keluarga dan masyarakat.

Dari uraian diatas maka penelitian ini bertujuan untuk mengetahui Pengaruh Layanan Informasi dalam Bimbingan Pribadi Terhadap Konsep Diri Siswa Kelas VIII SMP Swasta Maju Telaga Jernih Kecamatan Secanggang Tahun Pelajaran 2016/2017.

Konsep diri merupakan gambaran pandangan mengenai diri sendiri yang bersumber dari satu perangkat keyakinan dan sikap terhadap dirinya sendiri. Konsep diri adalah semua persepsi kita terhadap aspek diri yang meliputi aspek fisik, aspek sosial, dan aspek psikologis, yang didasarkan pada pengalaman dan interaksi kita dengan orang lain. Faktor - faktor yang mempengarui perkembangan individu dapat dikategorikan kedalam faktor internal melawan faktor eksternal, dan pengaruh normatif melawan pengaruh bukan normatif". Faktor internal adalah faktor pembawaan sejak lahir yang disebut heredity. Faktor heredity ini adalah segala yang dibawa sejak lahir, yang diterima anak dari orang tuanya. Sementara itu yang 
dimaksud faktor eksternal adalah faktor yang berpengaruh terhadap diri individu yang berasal dari lingkungan. Faktor lingkungan ini diperoleh individu berdasarkan pengalamannya selama berprilaku dalam lingkungan diluar dirinya.

Faktor-faktor yang mempengaruhi konsep diri antara lain : 1) Inteligensi. Inteligensi mempengaruhi penyesuaian diri seseorang terhadap lingkungannya, orang lain dan dirinya sendiri. Semakin tinggi taraf intreligensinya semakin baik penyesuaian dirinya dan lebih mampu bereaksi terhadap rangsangan lingkungan atau orang lain dengan cara yang dapat diterima. 2) Pendidikan. Seseorang yang mempunyai tingkat pendidikan yang tinggi akan meningkatkan prestasinya. Jika prestasinya meningkat maka konsep dirinya akan berubah. 3) Status Sosial Ekonomi. Status sosial seseorang mempengaruhi bagaimana penerimaan orang lain terhadap dirinya. Penerimaan lingkungan dapat mempengaruhi konsep diri seseorang. 4) Hubungan Keluarga. Seseorang yang mempunyai hubungan yang erat dengan seorang anggota keluarga akan mengidentifikasikan diri dengan orang lain dan ingin mengembangkan pola kepribadian yang sama. Bila tokoh ini sesama jenis, maka akan tergolong untuk mengembangkan konsep diri yang layak untuk jenis seksnya. 5) Orang Lain. Kita mengenal diri kita dengan mengenal orang lain terlebih dahulu. Bagaimana anda mengenal diri saya, akan membentuk konsep diri saya.

Jalaluddin Rahmat $(2005,105)$ Adapun ciri atau tanda individu memiliki konsep diri yang positif adalah :1) Individu yakin akan kemampuan mengatasi masalah. 2) Individu merasa setara dengan orang lain. 3) Individu menerima pujian tanpa rasa malu. 4) Individu menyadari bahwa setiap orang mempunyai berbagai perasaan, keinginan, perilaku yang tidak semuanya disetujui masyarakat. 5) Individu mampu memperbaiki dirinya. Konsep diri negatif memiliki ciri-ciri sebagai berikut: 1) Individu peka terhadap kritikan. 2) Individu responsif terhadap pujian. 3) Individu cenderung tidak disenangi orang lain. 4) Individu cenderung bersikap hiperkritis. 5) Individu bersikap pesimis terhadap kompetisi. Ada empat aspek konsep diri yang bersifat positif dan negatif : a. Konsep diri fisik. Konsep diri fisik berarti pandangan, pikiran, perasaan dan pemikiran individu terhadap fisiknya sendiri. b. Konsep diri psikis. Konsep diri psikis berarti pandangan, pikiran, perasaan dan penilaian individu terhadap pribadinya sendiri. c. Konsep diri sosial. Konsep diri sosial berarti pendangan, pikiran dan penilaian individu terhadap kecenderungan sosial yang ada pada dirinya sendiri, konsep diri sosial berkaitan dengan kemampuan yang berhubungan dengan dunia di luar dirinya, perasaan mampu, dan berharga dalam lingkup interaksi sosial. d. Konsep diri moral. Konsep diri moral berarti pandangan, pikiran, perasaan, dan penilaian individu terhadap moralitas dirinya sendiri, 
konsep diri moral berkaitan dengan nilai dan prinsip yang member arti dan arah bagi kehidupan seseorang.

Seseorang dapat mengenal diri pribadinya melalui orang lain. Jadi perkembangan konsep diri merupakan penciptaan sosial, hasil belajar kita melalui hubungan dengan orang lain. Interaksi individu dengan lingkungan tanpa disadari akan membentuk perilaku serta mempengaruhi konsep diri siswa. Kondisi lingkungan yang kurang mendukung akan membentuk konsep diri siswa. Agar tidak terjadi kesalahan dalam membentuk konsep diri, perlu adanya bimbingan dan konseling. Bimbingan dan konseling ini berupa proses layanan informasi dalam bimbingan pribadi sebagai tindakan membina siswa mengenal diri dalam pembentukan konsep diri. Perkembangan lingkungan yang kurang mendukung akan berpengaruh dalam diri siswa dalam membentuk konsep diri siswa. Kondisi yang semacam ini apabila tidak segera ditangani dan dibimbing akan mempengaruhi konsep diri yang negatif pada siswa. Oleh karena itu pelayanan informasi dalam bimbingan pribadi perlu ditingkatkan dan dikembangkan sehingga mampu membentuk perilaku siswa yang baik dalam diri siswa sehingga mampu membentuk konsep diri yang positif.

Layanan informasi adalah suatu kegiatan layanan yang diberikan dengan tujuan memberikan pemahaman kepada individu - individu yang berkepentingan tentang berbagai hal yang diperlukan untuk menjalankan suatu tugas atau kegiatan yang dikehendaki. Tujuan layanan informasi adalah 1. Membekali individu dengan berbagai pengetahuan tentang lingkungan yang diperlukan untuk memecahkan masalah yang dihadapi berkenaan dengan lingkungan sekitar, pendidikan, jabatan maupun social budaya. 2.Memungkinkan individu dapat menentukan arah hidupnya. 3.Setiap individu adalah unik, keunikan tersebut membawakan pola-pola pengambilan keputuan dan bertindak berbeda-beda sesuai dengan aspek kepribadian masing-masing individu. Namun Tujuan utama layanan informasi (dalam Lahmuddin Lubis : 53) ini "adalah untuk membekali siswa atau individu dengan berbagai pengetahuan dan pengalaman tentang berbagai hal yang berguna untuk mengenal diri, merencanakan dan mengembangkan pola kehidupan mereka sebagai siswa, anggota keluarga dan masyarakat.

Layanan informasi dalam bimbingan pribadi merupakan sebuah kegiatan pemahaman kepada siswa tentang berbagai hal yang diperlukan untuk menjalankan tugas dan kegiatan sekolah untuk menentukan dan mengarahkan tujuan hidup. Layanan Informasi dalam bimbingan pribadi, adalah suatu layanan yang memberikan informasi dalam diri pribadi. Artinya dapat mengembalikan, memberikan pengetahuan secara mendalam terhadap individu untuk menerima, berbagai informasi yang dapat dipergunakan sebagai pertimbangan dan 
pengambilan keputusan untuk kepentingan peserta didik kemampuan hubungan pribadi, sosial, teman sebaya, anggota keluarga dan warga lingkungan sosial yang lebih luas. Layanan informasi dalam bimbingan pribadi berisi materi layanan yang meliputi kegiatan pemberian orientasi tentang upaya mengenalkan bakat dan minat serta bentuk penyaluran serta usaha mengatasi berbagai permasalahan pribadi yang ditemui di rumah, sekolah dan masyarakat.

Pemahaman yang diperoleh melalui layanan informasi ini dapat digunakan sebagai bahan acuan dalam meningkatkan kegiatan dan prestasi belajar, mengembangkan cita-cita, menyelenggarakan kehidupan sehari-hari dan mengambil keputusan, sehingga bimbingan sebagai fungsi pemahaman dan pencegahan dapat dijalankan. Berjalannya fungsi ini dalam diri siswa membantu dalam membentuk konsep diri yang positif serta dapat mengurangi atau mempengaruhi terbentuknya konsep diri yang negatif, sehingga siswa memiliki motivasi dan berprestasi sesuai dengan bakat dan minat yang dimiliki dalam diri individu tersebut. Berdasarkan kajian yang telah dikemukakan di depan dapat dirumuskan hipotesis sebagai berikut :

Ha : Ada Pengaruh Layanan Informasi dalam Bimbingan Pribadi Terhadap Konsep Diri Siswa Kelas VIII Smp Swasta Maju Telaga Jernih Kecamatan Secanggang Tahun Pelajaran 2016/2017.

$\mathrm{H}_{0}$ : Tidak ada Pengaruh Layanan Informasi dalam Bimbingan Pribadi Terhadap Konsep Diri Siswa Kelas VIII Smp Swasta Maju Telaga Jernih Kecamatan Secanggang Tahun Pelajaran $2016 / 2017$.

\section{METODE PENELITIAN}

Penelitian ini menggunakan rancangan eksperimen pre-test-post-test control group design, pada desain ini kelompok eksperimen akan diberikan layanan informasi selama 45 menit dalam 5x pertemuan mengenai konsep diri, sedangkan untuk kelompok kontrol tidak diberi perlakuan. Kedua kelompok mendapatkan tes awal dan tes akhir dengan menggunakan Skala Konsep Diri. Dalam kegiatan ini yang menjadi objek penelitian adalah seluruh populasi kelas VIII SMP Swasta Maju Telaga Jernih Kecamatan Secanggang, yang terbagi atas dua kelas yaitu Kelas Eksperimen 30 orang dan kelas kontrol 30 orang. Penelitian ini dilakukan secara bertahap mulai dari tahap persiapan sampai tahap penyajian hasil penelitian, dengan urutan :

Tahap persiapan penelitian,

Persiapan merupakan tahap awal dari penelitian, adapun tahap persiapan yang akan dilakuakan adalah : 
a. Melakukan penjajakan terhadap subjek dan lokasi penelitian untuk memperoleh data awal sehingga mandapat gambaran yang lengkap dan jelas mengenai masalah yang akan diteliti.

b. Menentukan judul penelitian.

c. Mengurus surat izin untuk penelitian.

d. Menyusun desain kisi-kisi dan instrument penelitian.

e. Menentukan tempat dan waktu untuk melaksanakan penelitian.

f. Menetapkan siswa untuk dijadikan sampel penelitian.

Tahap pelaksanaan,

Setelah persiapan cukup, pelaksanaan penelitian dilakukan dengan :

a. Memberikan pretest kepada siswa kelas eksperimen dan kelas kontrol.

b. Melaksanakan Layanan Informasi dengan metode ceramah. Pemberian Layanan Informasi dilakukan terhadap kelompok eksperimen yang dilaksanakan dalam $5 \mathrm{x}$ pertemuan (dengan durasi waktu 45 menit setiap pertemuan) di ruang kelas VIII SMP Swasta Maju Telaga Jernih Kecamatan Secanggang. Sedangkan kelompok kontrol tidak diberi perlakuan.

c. Memberikan post-test kepada siswa kelas eksperimen dan kelas kontrol.

Tahap analisis data

Setelah kegiatan pelaksanaan selesai, yang akan dilakukan selanjutnya adalah mengumpulkan data yang diperoleh dari kelas eksperimen dan kelas kontrol untuk dianalisis, melakukan pengamatan terhadap perkembangan konsep diri siswa setelah diberi layanan informasi, serta menganalisis seluruh data dengan menggunakan teknik analisis yang telah ditentukan untuk mendapatkan hasil penelitian.

Pemberian layanan informasi kepada siswa dilakukan dengan metode ceramah, peneliti memberikan informasi mengenai konsep diri kepada siswa melalui tahapan - tahapan berikut :

1. Guru memberi pandangan mengenai konsep diri kepada siswa.

2. Guru Menerangkan materi sesuian Rencana Pelaksanaan Layanan (RPL) yang telah dibuat

3. Siswa diberi kesempatan untuk bertanya

4. Guru membuat suatu permasalahan yang akan dipecahkan bersama - sama

5. Setelah semua tahapan dilakukan, guru memberikan Angket yang harus diisi oleh siswa.

Dalam pelaksanaan kegiatan ini dilakukan didalam ruang kelas VIII SMP Swasta Maju Telaga Jernih Kecamatan Secanggang. Untuk memperoleh data yang diperlukan dalam penelitian ini peneliti menggunakan alat ukur skala. Skala yang digunakan untuk 
mengumpulkan data adalah Skala Likert. Skala likert merupakan bentuk skala dengan empat alternatif jawaban atau bobot jawaban untuk setiap pertanyaan item positif da item negatif subyek diminta memilih satu diantara empat jawaban yang tersedia yaitu: (SS) sangat setuju, (S) setuju, (TS) tidak setuju, (STS) sangat tidak setuju. Skala konsep diri terdiri dari 40 item, 20 item favorable dan 20 item unfavorable. Untuk mempermudah menghitung hasil yang diperoleh dari skala, maka setiap jawaban diberi skor. Adapun sistem skoring yang digunakan dalam skala ini adalah pada item pernyataan favorable untuk jawaban sangat setuju (SS) diberi skor 4, setuju (S) 3, tidak setuju (TS) 2 dan sangat tidak setuju (STS) Sedangkan untuk item pernyataan unfavorable penilaiannya yaitu sangat setuju (SS) diberi skor 1, setuju (S) 2, tidak setuju (TS) 3 dan sangat tidak setuju (STS) 4. Jika responden tidak mengisi angket yang disediakan, maka diberi skor 0 (nol), baik pada item favorable maupun item unfavorable.

Adapun variabel dalam penelitian ini adalah a. Konsep Diri (variabel Y) dan b. Layanan Informasi (variabel X)

1. Konsep diri adalah cara pandang menyeluruh tentang dirinya yang merupakan penilaian tentang diri, bagaimana individu memandang dan menilai diri dalam bersikap dan berperilaku sehingga akan mempengaruhi tindakan dan pandangan yang berdasarkan pada penilaian tentang diri siswa baik kondisi fisik maupun lingkungan terdekatnya. Skala yang digunakan untuk mengumpulkan data adalah skala konsep diri yang peneliti buat berdasarkan ciri-ciri konsep diri positif. Adapun indikator dari variabel konsep diri adalah : Yakin akan kemampuan mengatasi masalah. Merasa setara dengan orang lain. Menerima pujian tanpa rasa malu. Menyadari bahwa setiap orang mempunyai berbagai perasaan, keinginan, perilaku yang tidak semuanya disetujui masyarakat. Mampu memperbaiki diri.

2. Layanan informasi adalah bentuk layanan yang diberikan kepada peserta didik atau individu sebagai bahan pertimbangan dalam mengambil keputusan. Layanan Informasi dalam bimbingan pribadi adalah suatu layanan yang memberikan informasi dalam diri pribadi. Artinya dapat mengembalikan, memberikan pengetahuan secara mendalam terhadap individu untuk menerima, berbagai informasi yang dapat dipergunakan sebagai pertimbangan dan pengambilan keputusan untuk kepentingan peserta didik kemampuan hubungan pribadi, sosial, teman sebaya, anggota keluarga dan warga lingkungan sosial yang lebih luas.

Teknik yang digunakan untuk menghitung koefisien Pengaruh Layanan Informasi Terhadap Konsep Diri Siswa Kelas VIII di SMP Swasta Maju Telaga Jernih adalah 
menggunakan metode eksperimen dengan teknik pre-test dan post-test. Data yang terkumpul akan dianalisa menggunakan uji t untuk membandingkan post-test kelompok eksperimen dan kelompok kontrol. Selanjutnya untuk menguji pengaruh layanan informasi dalam bimbingan pribadi terhadap konsep diri siswa penelitian ini menggunakan metode regresi linear sederhana.

$\mathrm{Y}=\mathrm{a}+\mathrm{bX}$

Dimana :

$$
\begin{aligned}
& \mathrm{Y}=\text { Nilai yang diprediksikan } \\
& \mathrm{a}=\text { Konstanta Atau Bila Harga } \mathrm{X}=0 \\
& \mathrm{~b}=\text { Koefisien Regresi } \\
& \mathrm{X}=\text { Nilai Variabel Independen }
\end{aligned}
$$

\section{HASIL DAN PEMBAHASAN}

Berdasarkan hasil tes yang diberikan kepada siswa, baik diawal maupun diakhir pembelajaran diperoleh dua kelompok nilai, yaitu nilai kelompok eksperimen dan nilai kelompok kontrol. Berikut ini disajikan hasil tes konsep diri siswa dengan menyebarkan skala konsep diri pada kelompok eksperimen dan kelompok kontrol. Deskripsi secara lengkap digambarkan pada table berikut :

\begin{tabular}{|c|c|c|c|c|c|}
\hline No & Data & N & $\begin{array}{c}\text { Nilai } \\
\text { Maks }\end{array}$ & $\begin{array}{c}\text { Nilai } \\
\text { Min }\end{array}$ & Mean \\
\hline 1 & $\begin{array}{c}\text { Kelompok } \\
\text { Eksperimen }\end{array}$ & 30 & 120 & 103 & 110,3 \\
\hline 2 & $\begin{array}{c}\text { Kelompok } \\
\text { Kontrol }\end{array}$ & 30 & 117 & 96 & 106,6 \\
\hline
\end{tabular}

Hasil pre-test menunjukan bahwa nilai tertinggi kelompok eksperimen adalah 103 dan kelompok kontrol adalah 117. Kedua kelompok ini memiliki nilai tertinggi yang berbeda serta nilai rata-rata yang berbeda pula. Nilai rata- rata kelompok eksperimen adalah 110,3 sedangkan nilai rata- rata kelonpok kontrol adalah 106,6.

Ini menunjukan bahwa adanya perbedaan konsep diri siswa antara kelompok eksperimen dengan kelompok kontrol namun kedua kelompok masih memiliki varians yang homogen ditunjukan oleh hasil uji homogenitas varians diantara keduanya yang memberikan hasil bahwa kedua kelompok adalah homogen, sehingga kedua kelompok masih memenuhi syarat untuk dijadikan sebagai sampel penelitian. Berikut ini disajikan tabel data post-test :

\begin{tabular}{|l|l|l|l|l|l|}
\hline & & & Nilai & Nilai & \\
\hline
\end{tabular}




\begin{tabular}{|c|l|c|l|c|c|}
\hline No & \multicolumn{1}{|c|}{ Data } & N & Maks & Min & Mean \\
\hline 1 & $\begin{array}{l}\text { Kelas } \\
\text { Eksperimen }\end{array}$ & 30 & 150 & 119 & 135,2 \\
\hline 2 & $\begin{array}{l}\text { Kelas } \\
\text { Kontrol }\end{array}$ & 30 & 126 & 106 & 116,7 \\
\hline
\end{tabular}

Hasil post-test menunjukan bahwa nilai tertinggi dan terrendah yang diperoleh siswa pada kelompok eksperimen secara berturut-turut adalah 150 dan 119 dengan nilai rata-rata 135,2. Sedangkan nilai tertinggi dan terrendah yang diperoleh siswa pada kelompok kontrol secara berturut-turut adalah 126 dan 106 dengan nilai rata-rata 116,7.

Dilihat dari rata-rata hasil pre-test dan post-test masing- masing kelompok, didapatkan bahwa kelompok eksperimen mengalami kenaikan yang cukup besar dibandingkan dengan kelompok kontrol. Uji t dilakukan terhadap hasil pre-tset dan post-test pada kelompok eksperimen menunjukan adanya perbedaan hasil yang cukup signifikan antara sebelum dan sesudah diberikan perlakuan karena 15,37 > 1,699 sehingga $\mathrm{H}_{0}$ ditolak dan karena $\mathrm{t}_{\text {hiutng }}>\mathrm{t}_{\text {tabel }}$ maka dapat ditarik kesimpulan bahwa konsep diri siswa setelah diberikan perlakuan lebih baik dari pada sebelum diberikan perlakuan.

Selanjutnya uji hipotesis untuk mengetahui pengaruh layanan informasi dalam bimbingan pribadi terhadap konsep diri dilakukan dengan menggunakan metode regresi. Hasil analisis uji pengaruh didapatkan bahwa nilai $F_{\text {hitung }}>F_{\text {tabel }}(2.73>2.45)$ yang berarti bahwa Ha diterima. Dan dapat ditarik kesimpulan terdapat pengaruh yang signifikan antara layanan informasi dalam bimbingan pribadi terhadap konsep diri siswa kelas VIII SMP Swasta Maju Telaga Jernih Kecamatan Secanggang Tahun Pelajaran 2016/2017.

\section{REFERENSI}

Hasil analisis menunjukan setelah diberikan layanan informasi dalam bimbingan pribadi terhadap konsep diri, terdapat perbedaan antara kelompok eksperimen yang diberikan layanan informasi memiliki konsep diri lebih tinggi ( mean = 135,2 dan simpangan baku/ SD $=58,05)$ dari pada kelompok kontrol ( mean $=116,7$ dan simpangan baku/ $\mathrm{SD}=40,57)$. Hasil analisis uji hipotesis untuk mengetahui pengaruh layanan informasi dalam bimbingan pribadi terhadap konsep diri didapatkan hasil $\mathbf{F}_{\text {hitung }}>\mathbf{F}_{\text {tabel }}(\mathbf{2 . 7 3}>\mathbf{2 . 4 5})$ yang berarti bahwa Ha diterima. Dan dapat ditarik kesimpulan terdapat pengaruh yang signifikan antara layanan informasi dalam bimbingan pribadi terhadap konsep diri siswa kelas VIII SMP Swasta Maju Telaga Jernih Kecamatan Secanggang Tahun Pelajaran 2016/2017.

\section{REFERENSI}


Mulyani Sumantri dan Nana Syaodih, 2011. Perkembangan Peserta Didik. Universitas Terbuka.

Alex Sobur. 2003. Psikologi Umum Dalam Lintasan Sejarah. Pustaka Setia.

Lahmuddin Lubis. 2011. Landasan Formal Bimbingan Konseling di Indonesia. Citapustaka.

Muhammad Surya, 2014. Psikologi Guru Konsep dan Aplikasi. Alfabeta.

Jalaludin Rahmat. 2005. Psikologi Komunikasi. Rosda Karya.

Prayitno dan Erman Amti. 2009. Dasar-dasar Bimbingan dan Konseling. Rineka Cipta.

Lahmuddin Lubis. 2011. Landasan Formal Bimbingan dan Konseling di Indonesia. Cita Pustaka.

Prayitno dan Erman Amti. 2009. Dasar - dasar Bimbingan dan Konseling. Rineka Cipta. 